\title{
Changes in Consumer Purchasing Behavior Due to COVID- 19 Pandemic
}

\author{
Dr. Salma. Akter ${ }^{1} \quad$ Taj Ashrafi $^{2} \quad$ Dr. Victoria Waligo ${ }^{3}$ \\ 1.Assistant Professor. Department of Business Administration, East West University. Dhaka, Bangladesh \\ 2.Faculty Member, Bangladesh Korea Institute of Information and Communication Technology (BKIICT). \\ Dhaka, Bangladesh \\ 3.Director of Programmes - Tourism, School of Business, Middlesex University, London
}

\begin{abstract}
Due to the COVID-19 pandemic, the world is facing historical challenges without prior preparation. Because of the unavoidable economic crisis for the shutdown of numerous trade and industrial activities the COVID-19 pandemic has triggered substantial modifications in the habits of consumers all over the world. The pandemic has led to key changes in consumers purchasing and consumption behavior as the result of lockdown, social distancing, and uncertainty about the future due to its infectious nature. This study investigated the impact of the pandemic outbreak on consumers' purchasing and consumption behavior in a developing country such as Bangladesh. An online survey was conducted for collecting data about the changes in buying behavior through a structured questionnaire. The research targeted 200 respondents belonging to different age-gender segments, qualifications \& occupations, and household monthly income. The 191 completed responses had received and analyzed among 200 distributed structured questionnaires. The Partial Least Squares (PLS-SEM) method was applied, with the Smart PLS software v.3.3.2 for analyzing the proposed theoretical model and to test the developed hypotheses. The outcomes of the research strongly indicate that the health and safety concern, imposed restrictions, financial condition, surrounding environment-people, and other realities caused a remarkable change in consumer buying behavior. The outcomes of this study provide significant guidance to policy interventions, marketing decisions, and strategies for doing business as usual during and after the pandemic and perhaps add to the understanding of this unprecedented and ongoing phenomenon.
\end{abstract}

Keywords: COVID-19 pandemic, consumer behavior, TPB model, panic buying, online shopping, risks perception.

DOI: $10.7176 / \mathrm{JMCR} / 77-04$

Publication date:March $31^{\text {st }} 2021$

\section{Introduction}

The world faced challenges many times due to the outbreaks of risky and deadly contagious diseases such as severe acute respiratory syndrome (SARS) in China in 2002. In 2015, the world experienced again the Middle East respiratory syndrome (MERS) and Ebola virus which was found in West Africa. The inauguration of 2020 was remarked by the novel Coronavirus outbreak from Wuhan, China (COVID-19) (WHO 2020). The virus SARSCoV-2 is responsible for deadly COVID-19 spreads mainly from human contact, leading to respirational syndrome and deaths of older adults and persons of any age group with or without serious underlying health conditions (Jribi, S., Ben Ismail, H., Doggui, D. and Debbabi, H. 2020). In early December 2019, the COVID-19 virus was found in Wuhan (China) and spread quickly across China and 218 countries, areas, or territories with cases of catastrophic consequences - more than 39,596,858 confirmed cases of reported infections with more than 1,107,374 people dead (WHO, 18 October 2020). The World Health Organization confirmed COVID-19 as a pandemic on March 11, 2020 (WHO, 2020), after the declaration of COVID-19 as a worldwide pandemic, the first Covid-19 infected person in Bangladesh was identified on 8th March 2020. The Bangladesh Government declared lockdown on 26th March 2020 and most of the economic activities were restricted to reduce the transmission of COVID -19 (Rejve \& Iqbal, 2020). According to Siddika \& Islam (2020) the country went for complete lockdown since the 26th of March for two weeks and extended several times. Now the government has withdrawn lockdown but imposed several strict terms and conditions. The government has been reintegrating social distancing and two weeks of quarantine for all citizens if needed. Businesses are facing many new challenges, such as international borders sealed, bricks-and-mortar businesses closed their doors, and people are being told to stay at their home, temporary or even permanent closures were faced by many local and international companies, with staff facing months of economic insecurity and worry, also the buying behavior of the consumers has changed on a massive scale (Rao \& Moorthy, 2020). The situation has had a key influence on consumers and the retail area across the whole Europe and further afield (Feng \& Fay, 2020). Rao \& Moorthy, (2020) added that those in quarantine or under lockdown failed to continue their natural routines, particularly since many local retails have been forced to close their doors for health and safety reasons. Panic and bulk buying of items took place due to concerns about future availability. The COVID-19 financial insecurity and the predictions of a sharp and long-term economic stagnation had an impact on consumer buying behavior of 
essentials.

The purpose of this research paper is to find out the impact of the COVID-19 pandemic on the purchasing and consumption behavior of the consumers and to identify the significant factors that are affecting purchasing behavior. The research findings can inform marketing decision-makers, and adapt to similar disasters in the future.

\section{Literature Review}

In marketing research, the term "Purchase behavior" is an extensively recognized phenomenon. According to Engel, Blackwell, and Miniard (1986), consumer behavior could be described as the "act of individuals directly involved in obtaining and using economic goods and services, including the decision process that precedes and determine the acts". On the other hand, Daneshvary and Schwer (2000) defined the term as the "Consumer behavior is the study of how people buy, what they buy, when they buy, and why they buy and attempts to understand the buyer decision-making process both individually and in groups". The American Marketing Association defined consumer behavior as the vibrant interaction among effect, and perception, behavior, and the surrounding environment through which consumers conduct the needed exchange aspects of their lives (AMA, 2016).

From the above definitions, it could be mentioned that consumer behavior study provides marketers a clear guideline and reason to identify why consumers behave and respond differently in times of purchasing their goods and services. Consumer behavior explained the stimuli behind a consumer's purchase decision-making process and plays a significant role in the field of modern marketing.

Consumer's purchasing behavior is influenced and motivated by various factors such as in retail shopping, store environment is a fact (Chang, Eckman, \& Yan, 2011; Mitchell \& Harris, 2005; Rhee \& Bell, 2002), the product or service as the item of routine purchase or not (Bayley \& Nancarrow, 1998), brand preference (Mueller \& Szolnoki, 2010; Kaswengi \& Diallo, 2015;) and nature of crisis time purchasing (Ang, Leong, \& Kotler, 2000; Sneath, Lacey, \& Kennett-Hensel, 2009; Gázquez-Abad, Martínez-López, \& Esteban-Millat, 2017;).

A wide range of academic research focused on the point that planned (conscious) or impulse (subconscious) purchasing behavior is significantly guided through emotional or hedonic and utilitarian motivations ( $\mathrm{Yu} \&$ Bastin, 2010). According to Mansoor and Jalal, (2011) the consumer behavior could be defined as the study of the procedures where consumers make their purchasing choices for satisfying their needs. Generally, the purchase or buying behavior could be taken in many forms of buyer's choices that can differ depending on an extensive set of factors such as income level, demographic characteristics, social and cultural norms and factors. A large number of previous researches investigating customer's behavior also recognized perceptions, attitudes, and motivation level as important influencers on customers' beliefs and values (Haq \& Abbasi, 2016).

Besides the basic internal influential factors of the purchasing behavior, there are also a set of external stimulating factors that have strong influence such as external circumstances and the surrounding environment of the consumer. "Risk-averse consumption behavior" was perceived after several large-scale incidents for example terrorism (9/11), tsunamis, and earthquakes and also both during and after the natural disasters (e.g., hurricanes, tornadoes, wildfires, and floods) the downturns in economic activity and shifting in utilitarian and hedonic purchasing motivations can be observed (Larson and Shin, 2018). Covid-19 is playing as a strong external influence in case of the purchasing decision-making process. Because of its extreme contagious nature and imposed restrictions by the government, consumers need to maintain physical and social distancing and could not continue their as usual shopping like before the pandemic. Consumer behavior is an amalgamation of customer's purchasing consciousness which is also combined with several external motivators and de-motivators (Mansoor and Jalal, 2011).

However, in the crisis (economic, social, political) the consumers are subjected to systematic stress and the stress regulates them either to save money for accumulating resources which could offer security or to demonstrate an impulsive behavior in buying different products that they consider necessary (Durante and Laran, 2016).

During a pandemic, economic stability is straightly influenced by the shut-down of some divisions, reducing both the number of staffs and work hours and the obligation for government's massive investments which burdens the national budget and also full or partial suspending the business functions of companies, restriction on goods transportation, and closing international flights and state's borders create effects on trade, agriculture, tourism, and transport (Patel et al., 2015). According to the study of Centre for Retail Research UK., 20,000 retail outlets have been forecasted to close by the end of the year, whereas 4,547 already closed in 2019 . In addition, months of lockdown will be responsible for 235,000 jobs cut, increased from 93,000 in 2019 that was the most horrible and challenging year for retail and other business sectors (Munbodth, 2020).

In the situation of the spread of coronavirus, there are drastic ups and downs in the lifestyle of people and the business atmosphere around the world. There is a change in the priority of purchasing lists such as more emphasis on food items and less on the luxury goods and services sector (Stanciu et al., 2020). According to 
Stanciu et al. (2020), StartupCafe's (2020) publication quoted a conducted survey by the Nielsen Company based on the consumers of 100 countries which globally revealed a change in consumer behavior. Due to concerns of the coronavirus, a 6 stage process in the evolution of consumer behavior was identified. Proactive behavior which was targeted to general health and immunity-boosting activities were focused at the first stage. In the second stage, a responsive health management system was developed and consumers' demanded more protection related products. In the next third and fourth stages, the market supplies of COVID-19 protection products increased, quarantine started, and followed by different restrictions. The final stage will be how to get back to normal life which was mentioned as a new normal.

Due to the rapid escalation in demand, health care products, and commodities became seriously scarce when the COVID-19 pandemic started to broke out world-wide (Long and Khoi, 2020). Consumers changed their consumption patterns as they spend more time in homes, there is an increasing demand for takeout foods, snacks, alcohol, and cleaning items. The industries that are related to healthcare, medication, herbs, and vitamins are doing well. To boost up their immune system, consumers start purchasing healthy foods and vitamins. Consumers are also hoarding essential items, panic purchasing, and shifting to rural areas (Donthu and Gustafsson, 2020).

During the crisis time, there is a general tendency of a consumer is to postpone the purchase of durable goods such as automobiles, flats, properties, and appliances, etc., and spending on discretionary goods or services (Sheth, 2020). Avdiu and Nayyar, (2020) also added the demand for consumer durables has fallen more during previous crises.

Because of the COVID-19 pandemic, pent-up demand may lead to a major rebound in trades of durable products and consumers will come back in a purchasing mood before long. The Great Recession caused consumer behavioral and attitudinal deviations, the expenditure was declined in general and non-luxurious products were purchased (Zwanka and Buff, 2020) for instance the US; renowned brands such as Sears, JCPenney, Neiman Marcus, Hertz, and J. Crew are under massive financial stress during the COVID-19 crisis. Worldwide in terms of financial decisions and spending, consumers are more conservative and protective than ever because of future uncertainty (Donthu and Gustafsson, 2020). The recent Edelman Trust Barometer worldwide survey of 12,000 consumers showing that two-thirds of respondent consumers stated that their future buying decisions will be intensely influenced by the response of brands on the pandemic. Because of inappropriate response to the crisis, one-third have already switched brands, and the figure in Brazil rose to $76 \%$ and in India $60 \%$ (Rogers, 2020).

On the other hand, Donthu and Gustafsson, (2020) cited from Asmelash \& Cooper, (2020) that the travel business is extremely affected, the travel destinations failed to make any profits in 2020 and only $20 \%$ of hotel rooms are full, commercial airlines industry reduced their $90 \%$ of staffs. Zwanka and Buff, (2020) cited "The World Travel and Tourism Council (WTTC)" stated that if the travel and tourism industry want to recover their previous levels of participation they need to wait over a year. The WTTC's managing director Virginia Messina spoke to Reuters that due to the enthusiasm for VR (virtual reality) tourism sector could increase its business once it returns normal from the pandemic (Rogers, 2020). Virtual reality could be considered true in the travel and tourism industry as a vital transformation that permits people to participate in any adventures any corner in the world such as playing virtual poker, attending WWF wrestling, or climbing the highest mountaintops (Kirk and Rifkin, 2020).

Due to awareness, different medical supplies, hand rubbing alcohol, antibacterial surface wipes, first aid kits, antiseptics liquid and cream, remedies against cold and flu, and cough became a priority of the consumers (Nielsen 2020). As the population fulfilled their emergency health needs, then consumption arrangements shifted to stock-up and the categories such as rice, powdered milk, black beans, dried beans, chickpeas, canned meat, tuna, biscuits, water, pasta, etc. got high increases in sales (Zwanka and Buff, 2020). Several countries' consumers faced complete lockdowns such as Italy, China, the UK, India, South Korea, and others. These countries' consumers were not allowed to visit stores physically and stores came home through full online facilities and home delivery. The same also noticed in the case of education and work (Sheth, J., 2020).

Anderson et al. (2020) stated that in Denmark and Sweden a majority of the consumption changes during the COVID-19 pandemic are driven by changes in behaviors rather than restrictions or social distancing regulations. The aggregated consumption declined by 32 percent in the twelve-week post-outbreak period, with a much larger dropped in the Chinese city Wuhan (-70) percent. Dining and entertainment drop the most $(-64)$ percent, tailed by travel-related consumption (-59) percent and durable goods consumption (-35) percent. The expenditure category least affected was the groceries and household items (-15) percent. In addition, "used transaction-level household financial data" analyzed by Baker et al. (2020) on the spending behavior of a sample of the American population to analyze the impact of the COVID-19 outbreak showed that, before 27 March, overall consumption was down twenty-five percent for the week of 18-27 March, expenditure on restaurants was down 32 percent while 23 percent expenditure was up on grocery items. Furthermore, the analyzed data on bank spending in England and Wales by Cook et al. (2020) indicated that for the first two weeks of lockdown sales at 
non-grocery traders cut down by around 45 percent, while the spending at grocery sellers rose by 16 percent.

The customers left their existing retailers who are few miles away and lockdown forced them to shop from nearby family-run mom and pop shops. Due to the fear of deadly Coronavirus, there is a compromise in quality, shrink in quantity, and switch of consumer brands. Indeed those who were used to shop from supermarkets, shopping malls, and stores located in the city-heart now have to purchase the necessities from neighboring stores (Sharma, 2020).

Because of the pandemic, most of the people staying home and the homes are turned into offices, classrooms, doctors' offices, broadcast studios, gyms, worship places (Kirk and Rifkin, 2020). The practical consequence is that the virtual platforms replaced the customarily face-to-face activities as consumers become more adapted to online interfaces for conducting activities such as business, educational programming, and engaging in a wide range of social activities (Cohen, 2020). During the quarantine time, consumers have accepted different new technologies and applications for example zoom video communication services to maintain regular contact with family and friends, attending online classes at home as schools and colleges were closed, and app and website based telehealth services for virtual visits and important advice from the doctors and health care workers. Additionally, consumers are using different social media platforms including Facebook, WhatsApp, WeChat, LinkedIn, and video streaming platforms like Youtube and other OTT media services such as Netflix, Disney, Amazon prime etc. have a global reach. There is a mind-boggling global reach and acceptance of the social gathering via different social media such as Facebook, Zoom, and WhatsApp, and each platform has billions of subscribers or users (Sheth, 2020). The pandemic has led to a sharp increase in online trade (Dannenberg, 2020).

For preventing the spread out of COVID 19 people are staying home, but in this quarantine time people continue their buying online, as a result, there is a significant surge in online buying and also a surge in sales of two commodities such as healthcare and essential goods (Rao \& Moorthy, 2020). "In-home delivery of everything including streaming services such as Disney, Netflix, and Amazon Prime is breaking the odd habits of physically going to brick and mortar places. It is also enhancing convenience and personalization in consumer behavior" (Sheth, 2020). He also added "with more flexible time at home consumers are becoming producers with profitable opportunities", they are experimenting with recipes, and practicing their talent for example YouTube and its counterparts are filled with innovative videos. Americans are spending more time in the kitchen, trying new recipes happily, and gained confidence with expectations that they would continue to cook more even after the pandemic. Surprisingly they admitted that in this pandemic time they are cooking more which could be compared with their last fifty years of cooking habits. Because of the disruptions of product availability, many consumers are fulfilling their utilitarian necessities through self-made products such as home cooking or making protective face masks. This pandemic situation motivates consumers to involve in many "do-it-yourself" tasks. A large number of consumers have engaged in do-it-yourself assignments and housebound activities such as cooking foods, baking, gardening, different family games, etc. Home renovation and painting both were doubled in March 2020 which also enhanced sales for retailers (Kirk and Rifkin, 2020). Bangladesh, with a population of more than 160 million is a densely populated country in the world (Islam \& Khan, 2017). The country's economy is booming in recent years. Compared to the world context, COVID-19 occurrence and date rate is $0.003 \%$ only in Bangladesh but panic spread all over the country (Alam et al. 2020). The research conducted by LankaBangla Asset Management Company Limited, (2020) showing that during the COVID-19 closure, the number of online purchases via the e-commerce platforms such as daraz.com, shwapno.com, chaldal.com, etc. have been increased and have a significant increase in online orders in Bangladesh. The Bangladesh-based website chaldal.com's average 5000 orders-per-day jumped to 10,000 to 15,000 per day. The othoba.com of the RFL group experienced a booming rise of orders of PPEs and other hygiene and necessary products during the COVID-19 crisis. Because of panic buying online purchase of medicine, safety and sanitizing kits, has amplified. The leading digital storefront pharmacy store pharmacy.com archived a substantial upsurge in sales. As almost all the restaurants were closed and $30 \%$ of restaurants left business the food delivery service such as Foodpanda, HungryNaki, UBEREats, Pathao Food, ShohozFood, etc. are struggling and have faced a severe challenge in lockdowns on April and May (2020), their orders fell by 75 to $80 \%$.

\subsection{Theoretical Framework}

For addressing the research objective the Theory of Planned Behavior (TPB) of Fishbein and Ajzen (1991) has been applied with three core factors, such as attitude, subject norms, and perceived behavior control, and considered the influences of Risk Perception of COVID-19 on independent variables, before affecting the consumers buying purpose. The TPB model is evaluated as an operational model in practice to measure and anticipate behavior because of the high chance of success while conducting research, decision making in unusual situations like any natural disasters or epidemics, numerous studies have applied this model as a fundamental theory to recognize consumers' purchasing intentions (Long and Khoi, 2020). According to the TPB model, the behavioral intention is always organized through a vibrant synthesis of the attitude, subjective norm, and 
perceived behavioral controller variables, and the actual behavior is developed mainly from behavioral intention (Bray, 2008). From the theoretical basis, the study proposed the expected research model underneath:

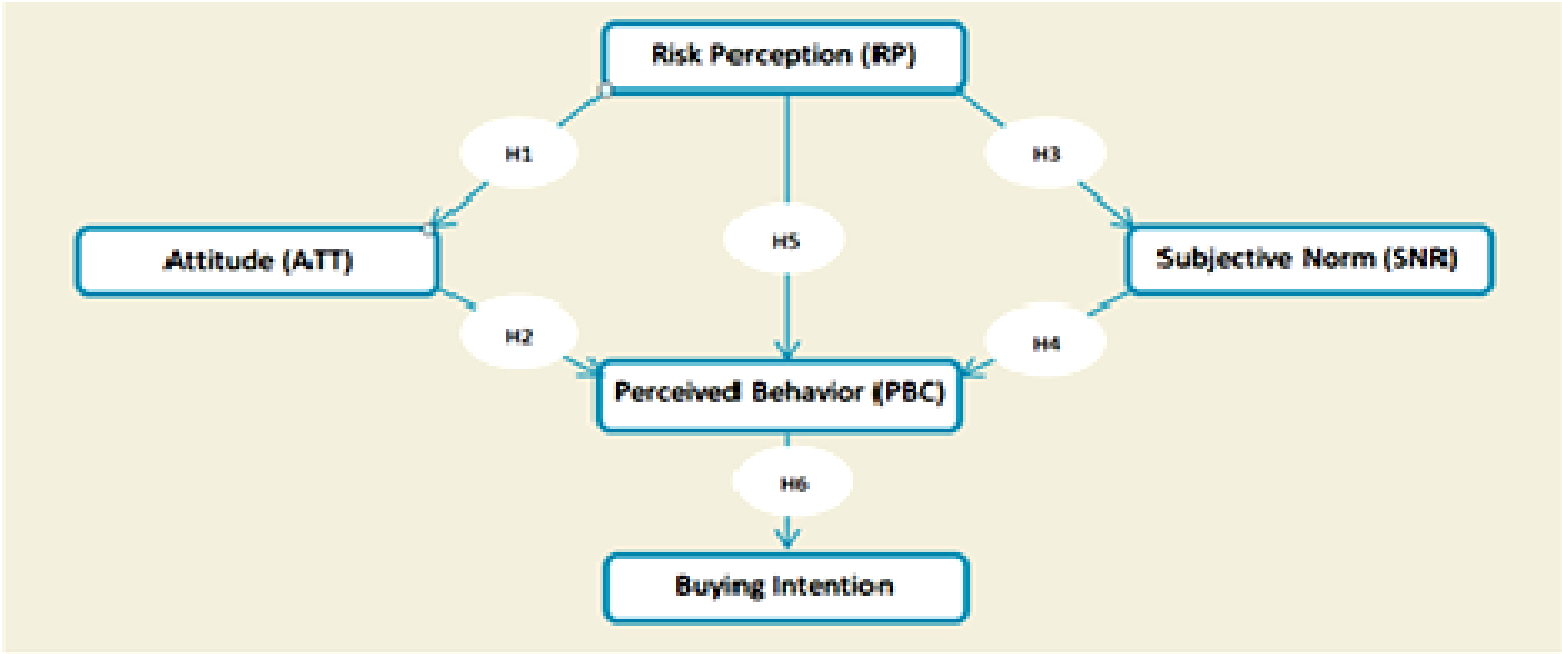

Figure 1: Investigation Model developed by the researcher.

Attitude (ATT): According to the TPB, attitude is the function of an individual's underlying views regarding the results that could be attained through engaging in the behavior or it states an individual's attitude toward engaging in a specific behavior (Long and Khoi, 2020). Due to the COVID-19 pandemic, consumers felt health-safety risks (e.g. infection), pricing risks, product quality, and availability risks, and these risk perceptions may be in a similar direction to the attitude of consumption. Therefore, hypothesis 1 indicates that:

H1: Risk perception has a positive influence on the Attitude of consumers' buying intention.

TPB model developed Ajzen (1991), belief can affect attitude that in turn could influence the buying intention. According to Long and Khoi, (2020) in the theory, attitude is an important function of the underlying views of an individual regarding the outcomes which can be accomplished by involving in the behavior. They defined attitude as assessing belief which may be expressed in both positive and negative mental state from someone if they need to engage in the behavior that will be ascertained. The attitude toward a behavior is determined by strong beliefs and that strong belief inspires an individual to take any decision or select any particular product (Hamdah et al., 2020). Huynh \& Nguyen, (2020) stated that in Vietnam people showed good awareness and a positive approach toward COVID-19.

Thus, Hypothesis 2 as follows:

$\mathrm{H} 2$ : The attitude certainly influences the Perceived Behavior of buyers in buying intention.

Subjective Norm (SNR): Social norms influence an individual's decisions as 'Subjective Norm': “what they observe others are doing or accept or reject" (Van Bavel et al., 2020). The subjective norm refers to social stresses or pressures which encourage or discourage an individual to take a particular action and the risk perception also a major antecedent of subjective norms. During the COVID-19 pandemic, strong peer pressures to follow societal norms such as social isolation provide shields against health challenges and risks in society (Bae and Chang, 2020). Hence, H3 is hypothesized as:

H3: The risk perception certainly influences consumers Subjective Norm in buying intention.

The subjective norm is an important factor that motivates the consumer to purchase. In particular, subjective norms are the major driver of behavioral intention. Campbell, (2020) depicted that even in the peak of the pandemic, the Korean government didn't impose any strict restriction on movement, though, the people's behaviors were influenced and shaped by the societal pressure to conform with preventive behaviors such as social distancing, wearing face-mask, and repeated hand-washing practice to avoid social blame. Thus, H4 is hypothesized as follows

H4: The subjective Norm impacts positively the Perceived Behavior of consumers in purchasing intention.

Perceived Behavioral Control (PBC): In planned behavior theory the key role is played by Perceived behavioral control. Perceived behavioral control denotes an individual's perception of the comfort or difficulty of executing the behavior of interest and it can, and usually does, differ through circumstances and actions (Ajzen, 1991). So far, many studies have acknowledged that there is an impact of risk perception on behavior in people's life, as well as consumer behavior. The dimension of the risk-level varies with circumstances and the consumers' decision-making process is determined by the "level of cost, benefit, level of damage, and level of risk appetite". Prior studies reflected Risk Perception for example an important factor that strongly influencing both purchasing decisions and intention (Long and Khoi, 2020). So hypothesis H5 as follows:

H5: The risk perception positively motivates consumers Perceived Behavior in purchasing intention. 
Deng et al., (2017) explained that the perceived behavior clarifies consumer decisions are repeatedly guided by psychological factors such as worries over-exhaustion, unavailability of products, insecurity about the financial limit which can't satisfy the deficiency situation when the inadequacy happens, and especially the panic triggered by "herd behavior". When the panic perceived everywhere, consumers never perform reasonably again, they start to purchase heavily which is more than actually, they need, the list of products will be irregular and a lot of people will be unable to buy because of the emptiness of the place of sale (Long and Khoi, 2020). When social turmoil develops the monetary burden is on everybody because of the significant expenditure of essential purchasing and hoarding. Various studies have reported a positive correlation between behavioral control and behavioral intention (Chen and Hung, 2016.). Therefore, Hypothesis 6 (H6) as follows:

H6: Perceived Behavior positively influences the Intention of consumers buying.

\section{Methodology}

\subsection{Sample}

The quantitative investigation method has been used to conduct the research. This method was chosen because it is popular in the area of consumer behavior for simplifying the results (Chrysochou, 2017). For directing the study, Likert-scale survey questionnaires have been used to get primary data to examine. This survey was carried out by online questionnaire distribution. A 7-day online survey was carried out for this study which was from August 23 to 30,2020. The online survey participants were chosen through a convenience sampling method and the survey link was provided via social media and mobile messenger and e-mail. Because of the global pandemic, it is not possible to interview people face to face so the chosen tool is appropriate. The online questionnaire provides more safety for researchers and respondents against the infection of the Covid-19 virus. The survey deliberated questions that clearly focused on different motivating and relevant factors which impacted the consumers' intention to purchase during the COVID-19 pandemic.

A total of 200 questionnaires were distributed for the survey and among them, 191 valid responses were accepted and used for the purpose of data analysis after removing nine incomplete questionnaires.

The questionnaire was divided into six sections: Risk perception, Attitude, Subjective norms, Perceived behavioral control, Buying purpose, and Demography related information. The amount of a person's perception of COVID-19 risk was defined as the risk perception. Afterward, the four variables of the TPB Model (i.e. Attitude, Subjective norms, Perceived behavioral control, and Behavioral intention towards buying) during the pandemic were measured with four items each.

In this research, the buying intention was defined as the purchasing behavior and trends of the consumer while avoiding or minimizing direct or in-store purchasing for health and safety reasons. All determinants were estimated on a 5-point Likert scale 1: strongly disagree; to 5: strongly agree and the asked demographic information was regarding gender, age, income level. 200 Bangladeshi consumers were selected by convenient sampling methods as respondents. There were $123(64.4 \%)$ males and $68(35.6 \%)$ females in this study and their age groups and income level were presented in the following Table 1 and Table 2.

Table 1: Respondents Age groups

\begin{tabular}{|cc|c|c|c|c|}
\hline \multicolumn{2}{c|}{ Age groups } & Frequency & Percent & Valid Percent & Cumulative Percent \\
\hline \multirow{4}{*}{ Valid } & 18-24 years & 54 & 28.3 & 28.3 & 28.3 \\
& 25-31 Years & 52 & 27.2 & 27.2 & 55.5 \\
& 32-38 years & 32 & 16.8 & 16.8 & 72.3 \\
& 39-45 years & 30 & 15.7 & 15.7 & 88.0 \\
& 45-52 years & 23 & 12.0 & 12.0 & 100.0 \\
& Total & 191 & 100.0 & 100.0 & \\
\hline
\end{tabular}

Table 2: Respondent's Income Level

\begin{tabular}{|c|c|c|c|c|c|}
\hline & Income Level & Frequency & Percent & Valid Percent & $\begin{array}{c}\text { Cumulative } \\
\text { Percent }\end{array}$ \\
\hline Valid & $\begin{array}{l}0-20000 \\
20001-30000 \\
30001-50000 \\
50000-70000 \\
70001-90000 \\
90001-110000 \\
110001 \text { and above } \\
\text { Total }\end{array}$ & $\begin{array}{c}72 \\
1 \\
25 \\
24 \\
34 \\
13 \\
22 \\
191\end{array}$ & $\begin{array}{c}37.7 \\
.5 \\
13.1 \\
12.6 \\
17.8 \\
6.8 \\
11.5 \\
100.0\end{array}$ & $\begin{array}{c}37.7 \\
.5 \\
13.1 \\
12.6 \\
17.8 \\
6.8 \\
11.5 \\
100.0\end{array}$ & $\begin{array}{c}37.7 \\
38.2 \\
51.3 \\
63.9 \\
81.7 \\
88.5 \\
100.0\end{array}$ \\
\hline
\end{tabular}




\subsection{Structural Model Assessment}

The Partial Least Squares (PLS-SEM) technique was applied, with the Smart PLS software v.3.3.2 for analyzing the proposed theoretical model and to test the developed hypotheses. The partial least squares structural equation model (PLS-SEM) first started by Herman Wold more than 20 years ago (1960s-1980s) and has been progressed further by his fellows (Lohmöller, 2013). The measurement model analysis associated the "reliability and validity of the constructs, as well as the structural model through R2, the path coefficients, the confidence intervals, and the values of the Standardized Root Mean Square (SRMR) as a measure of approximate fit of the model for PLS-SEM" (Henseler et al., 2015).

The Investigation model has been checked on the set of data for the Behavioral intention towards buying during the COVID-19 pandemic. The reliability and validity both were examined by Cronbach's alpha $(\alpha)$, average variance extracted $(\rho v c)$, and composite reliability $(\rho c)$. Cronbach's alpha coefficient higher than 0.6 would guarantee the scale's reliability, Pc should be greater than 0.6 and $\rho v c$ must be greater than 0.5 (Long and Khoi, 2020). Hair Jr et al., (2016) explained that PLS could be associated with the agreement of independent variables to various dependent variables.

\section{Results}

\subsection{Measurement Model:}

The measurement model estimates the reliability and validity of the variables. According to Henseler et al., (2016) Cronbach's alpha and Composite reliability $(\mathrm{Pc})$ are used to validate the construct's reliability. To authenticate the construct's reliability, both Cronbach's alpha and Composite reliability (Pc) values must be greater than 0.60 (Hair Jr et al., 2016). This research found the Cronbach's alpha of the constructs between 0.798 to 0.885 and the Composite reliability (Pc) between 0.869 to 0.921 . All alpha values of the constructs were exceeding the cut-off point of 0.7 , which indicates the acceptable reliability aimed at each construct (Table 3 ).

Table 3: Construct's Reliability and Validity

\begin{tabular}{|l|l|l|l|l|}
\hline Constructs & $\begin{array}{l}\text { Cronbach's alpha } \\
(\alpha)\end{array}$ & $\begin{array}{l}\text { rho_- } \\
\mathbf{A}^{-}\end{array}$ & $\begin{array}{l}\text { Composite Reliability } \\
(\rho \boldsymbol{c})\end{array}$ & $\begin{array}{l}\text { Average Variance Extracted } \\
(\boldsymbol{\rho} \boldsymbol{c})\end{array}$ \\
\hline Attitude (ATT) & 0.798 & 0.808 & 0.869 & 0.624 \\
\hline $\begin{array}{l}\text { Perceived Behavior } \\
\text { (PBC) }\end{array}$ & 0.832 & 0.835 & 0.888 & 0.666 \\
\hline $\begin{array}{l}\text { Subjective Norm } \\
\text { (SNR) }\end{array}$ & 0.871 & 0.873 & 0.907 & 0.663 \\
\hline Buying Intention (BI) & 0.878 & 0.880 & 0.905 & 0.578 \\
\hline Risk Perception (RP) & 0.885 & 0.889 & 0.921 & 0.746 \\
\hline
\end{tabular}

Additionally, the Average Variance Extracted $(\rho v c)$ and rho_A values of the constructs should be greater than 0.50 (Henseler et al., 2016). The values of Average Variance Extracted $(\rho v c)$ and rho_A have been noted from 0.624 to 0.746 and 0.808 to 0.885 (Table 3 ). The outcomes of conducting research are establishing convergent validity effectively. Therefore, the measurement model of research-validated positively.

Furthermore, discriminant validity is applied to authenticate the construct's external consistency. The discriminant validity can be assessed based on the Fornell-Larcker Criterion and Heterotrait Monotrait Ratio of Correlations (HTMT) (Long and Khoi, 2020). Henseler et al., (2016) stated that according to Fornell-Larcker Criterion, the square roots of $(\rho v c)$ should be more than other constructs vertically in a column.

Table 4: Fornell - Larcker Criterion

\begin{tabular}{|l|l|l|l|l|l|}
\hline & $\begin{array}{l}\text { Attitude } \\
\text { (ATT) }\end{array}$ & $\begin{array}{l}\text { Buying } \\
\text { Intention(BI) }\end{array}$ & $\begin{array}{l}\text { Perceived } \\
\text { Behavior(PBC) }\end{array}$ & $\begin{array}{l}\text { Risk } \\
\text { Perception(R } \\
\text { P) }\end{array}$ & $\begin{array}{l}\text { Subjective } \\
\text { Norm(SNR) }\end{array}$ \\
\hline Attitude (ATT) & 0.790 & & & & \\
\hline Buying Intention (BI) & 0.761 & 0.761 & & & \\
\hline $\begin{array}{l}\text { Perceived Behavior } \\
\text { Control (PBC) }\end{array}$ & 0.763 & 0.840 & 0.816 & & \\
\hline Risk Perception (RP) & 0.788 & 0.733 & 0.754 & 0.864 & \\
\hline $\begin{array}{l}\text { Subjective Norm } \\
\text { (SNR) }\end{array}$ & 0.715 & 0.710 & 0.779 & 0.726 & 0.814 \\
\hline
\end{tabular}

They also added that the HTMT index offers the latest criteria, which is beneficial to measure the construct's external consistency and the values of HTMT should be less than 1 . 
Table 5: Heterotrait-Monotrait Ratio (HTMT)

\begin{tabular}{|l|l|l|l|l|}
\hline Constructs & $\begin{array}{l}\text { Attitude } \\
\text { (ATT) }\end{array}$ & $\begin{array}{l}\text { Buying Intention } \\
\text { (BI) }\end{array}$ & $\begin{array}{l}\text { Perceived Behavior } \\
\text { (PBC) }\end{array}$ & $\begin{array}{l}\text { Risk Perception } \\
\text { (RP) }\end{array}$ \\
\hline Attitude (ATT) & & & & \\
\hline Buying Intention (BI) & 0.908 & & & \\
\hline $\begin{array}{l}\text { Perceived Behavioral } \\
\text { Control (PBC) }\end{array}$ & 0.935 & 0.977 & & \\
\hline Risk Perception (RP) & 0.929 & 0.831 & 0.88 & 0.826 \\
\hline Subjective Norm (SNR) & 0.858 & 0.813 & 0.915 & \\
\hline
\end{tabular}

The HTML index is applied to overcome the inadequacy in Fornell-Larcker Criterion and the crossloadings. The shown result in Table 4 and Table 5 illustrated that the constructs have approved the validity assessment and all values have been detected within the margins.

To make the final decision if the developed hypothesis would be accepted or rejected the research work has been evaluated the structural model. For verifying the relationship between constructs the path coefficient has been used. The bootstrapping technique was applied to track the PLS coefficient or path co-efficient. According to Long and Khoi, (2020) the PLS could be explained as a "regression model, which can handle the one or more dependent variables with a set of one or more independent variables, or it can be implemented as a path model".

Table 6: The direct relationship between the constructs (Note: $\mathrm{p}<0.1 * \mathrm{p}<0.05^{* *} \mathrm{p}<0.01 * * *$ )

\begin{tabular}{|l|l|l|l|l|l|}
\hline Hypothesis & Coefficients $(\beta)$ & STDEV & T Values & P Values & Impact \\
\hline$($ ATT $)>($ PBC $)$ & 0.293 & 0.064 & 4.602 & 0.000 & Accepted \\
\hline$($ PBC $)>(B I)$ & 0.840 & 0.033 & 25.849 & 0.000 & Accepted \\
\hline$(\mathrm{RP})>($ ATT $)$ & 0.788 & 0.040 & 19.715 & 0.000 & Accepted \\
\hline$(\mathrm{RP})>(\mathrm{PBC})$ & 0.231 & 0.071 & 3.261 & 0.001 & Accepted \\
\hline$(\mathrm{RP})>(\mathrm{SNR})$ & 0.726 & 0.044 & 16.549 & 0.000 & Accepted \\
\hline$(\mathrm{SNR})>(\mathrm{PBC})$ & 0.401 & 0.067 & 6.010 & 0.000 & Accepted \\
\hline
\end{tabular}

The bootstrapping method retrieved the result of the significance level, and the t-value should be more than 1.96 given a significance level of 0.05 . This conducted research has run the bootstrapping at 5000 sub-samples and the retrieved findings are represented in Table 6 and Figure 2. As demonstrated in Table 6, the analysis includes all the path coefficients $(\beta)$, Standard Deviation (STDEV), t-values, and p-values. According to the results, all of the research hypotheses are accepted.

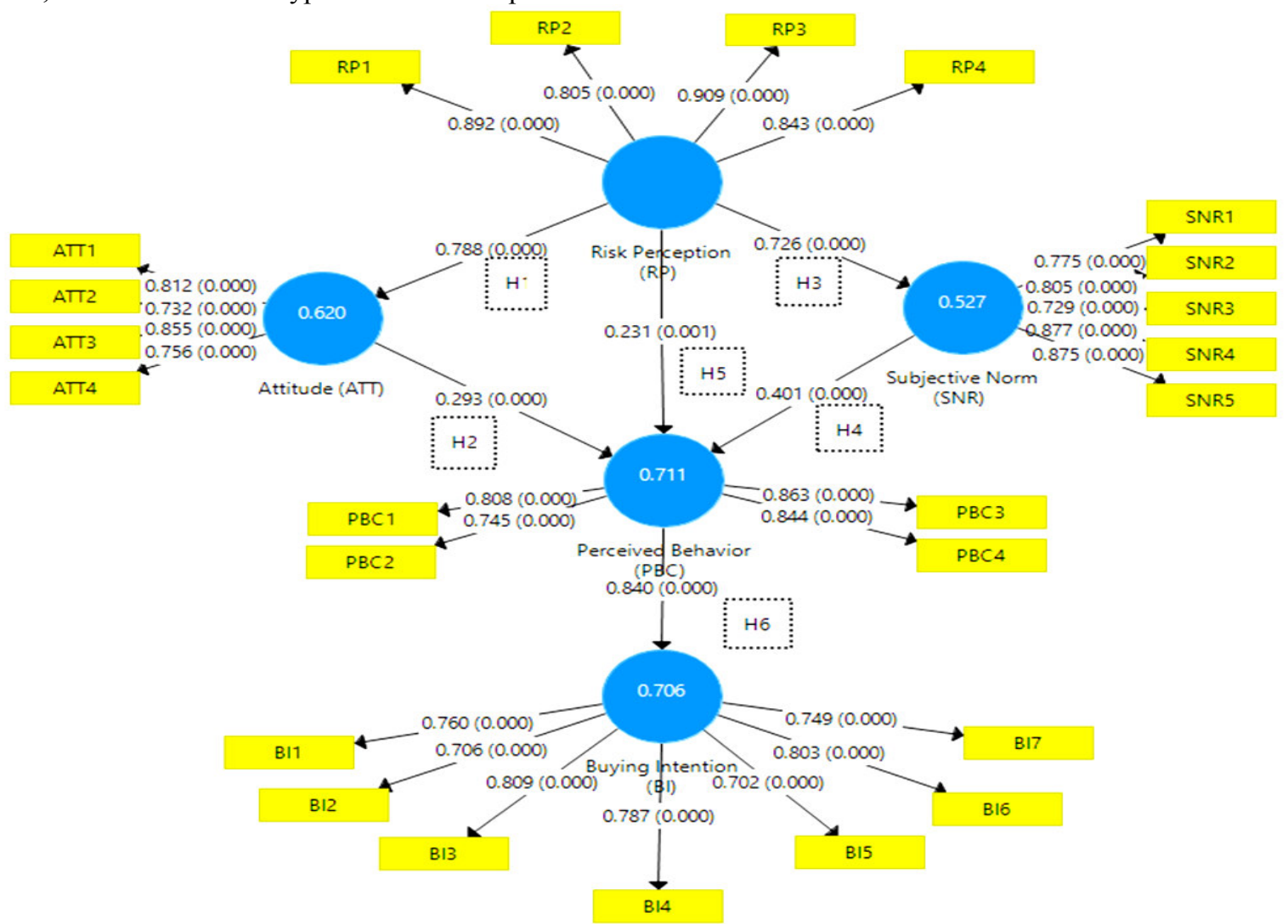

Figure 2: Measurement 1 Model 
The model power is explained by the coefficient of determination $\left(\mathrm{R}^{2}\right.$ or r-squared). The value of $\mathrm{R}^{2}$ is 0 to 1 ; the higher values represent the higher determination. The $\mathrm{R}^{2}$ values for example 0.75 represent higher determination, 0.50 moderated determinations, and 0.25 small determinations respectively (Long and Khoi, 2020). The outcomes showed that all of the aspects are significantly related to consumer purchasing behavior during the COVID-19 pandemic. During the COVID-19 pandemic situation Attitude, Subjective Norm significantly related to Perceived Behavior Control and the Perceived Behavior Control extensively related to the Buying Intention at $p<0.05$. Thus, according to the analyzed data, there is a significant change in purchasing behavior and trends of consumers due to the COVID- 19 outbreak.

Table 7: Model fit

\begin{tabular}{|l|l|l|}
\hline Indicators & Saturated Model & Estimated Model \\
\hline SRMR & 0.057 & 0.060 \\
\hline d_ULS & 0.970 & 1.089 \\
\hline d_G & 1.013 & 1.044 \\
\hline Chi-Square & 815.707 & 835.368 \\
\hline NFI & 0.771 & 0.766 \\
\hline
\end{tabular}

The results in Table-7 (Model fit) have shown that the Chi-square $=517.661$ was substantial at the 0.05 level ( $\mathrm{p}=0.00$ ). The SRMR (standardized root mean square residual) is the extent of the estimated model fit of the anticipated research model. A model had a good model fit when SRMR was less than 0.08 (Hu \& Bentler, 1998). The reported outcomes in Table- 7 revealed that the model required SRMR $=0.057<0.08$. Subsequently, the projected model was well fitted for the analyzed data.

\section{Discussion}

This study demonstrated a sudden upsurge in the consumption of goods in certain sectors such as disinfectants, healthcare, internet, media, etc. and these changes simultaneously led to a change in the nation's economy. Most of the researchers such as Donthu and Gustafsson, 2020; Zwanka and Buff, 2020; Kirk and Rifkin, 2020; Dannenberg, 2020 focused on selling in several sectors due to the COVID-19 pandemic and imposed lockdown. But, the area of changes in consumer buying behavior was less observed.

This research is designed to identify and examine the influence of COVID-19 risk perception on behavioral intention towards purchasing through the pandemic situation applying a comprehensive TPB. In precise, it focuses significant insights regarding the changes in purchasing behavior and goods in developing countries such as Bangladesh due to the COVID- 19 outbreak. This research provides comparatively different outcomes from earlier studies (such as Long and Khoi, 2020; Hamdah et al., 2020; Huynh \& Nguyen, 2020) after considering the risk perception factor to the given TPB model. In this study risk perception positively impacted purchasing intention.

\subsection{The key findings of this research are as follows:}

The outcomes identify that attitude towards perceived behavior control was absolutely related to the COVID-19 risk perception. People with a fearful attitude always try to avoid potential damage with progressive awareness. On the other hand, the people with a positive attitude to avoid risk, intense emotion of worry for the risks and could perform intense acts like panic buying and hoarding. In this study, the researchers applied the TPB model and consumer risk perception theory together to recognize the factors which influence the consumers' buying behavior during the Covid-19 pandemic. This confirms that consumer psychology is playing a key role in times of their purchase decision. As the research hypothesizes H1 and H2 show the risk perception of the Covid-19 pandemic has a positive effect on attitudes towards perceived behavioral control that consequently influenced the intention to purchase by Bangladeshi consumers.

Hypothesis H3 is also supported by the study, therefore, it indicates the subjective norms to buying intention were strongly influenced by the risk perception and confirm the effect of the observed threat of contagious syndrome on conformity to public norms. During the COVID-19 pandemic, powerful peer pressures to adapt to social norms for example social distancing could provide barriers against health and safety risks in society. Such sociocultural consent in Bangladesh can be clarified by the impact of people's risk perception.

Subjective Norm is an important intermediary between consumer's risk perception and behavioral intention. During the pandemic, the main driver to keep the massive infection level low is people's assent with protective behaviors such as wearing face- and social isolation. The preventive behaviors mostly develop from peer pressures because the people against that normative behaviors receiving blame and odium from the people around them. Particularly in uncertain situations, people learn and adopt heuristic progressions for adopting normative behaviors (Eidelman \& Crandall, 2009).

The attitude, subjective norms, and perceived behavioral control certainly influence behavioral intention that is also supported by sufficient outcomes from earlier TPB researches (Bae \& Chang, 2020). According to this study, the Attitude (ATT) and Subjective Norm (SNR) clearly influenced Perceived Behavior Control (PBC) 
variables (Attitude (ATT) 29.3\% and Subjective Norm (SNR) 40.1\%). Moreover, the Risk Perception (RP) variable intensely influences Attitude (78.8\%) and Subjective Norm (72.6\%), and only 23.1\% impacted on Perceived Behavior. According to the results, this can be stated that when the consumers identified the threats of a pandemic strongly, they could influence the views of others around them regarding the risks, and it can also stimulate their approach to deal with challenges from the outer environment. Then, sequentially, the attitude concerning consumer's intention to involve any particular activity has an active influence on their behavioral perception. Also, the conducted study outcomes show that the Perceived Behavior Control exerted the lowest influence $(29.3 \%)$ on the consumer's Attitude. So the influence of Risk Perception (RP) on Perceived behavior (PBC) is $23.1 \%$ and is not as strong as that on other variables. On the other hand, the outcomes of the research show that, the Perceived behavior (PBC) has a noteworthy effect on consumer's Buying Intention (BI) and which is $84.0 \%$.

\section{Conclusion and Implications of the Study}

The conducted research provides an appropriate and expressive explanation of the impact of the COVID-19 pandemic on the behavioral modifications among consumers. This study offered several theoretical implications to knowledge which were mainly based on the collected data and in-depth analysis at the stage of the pandemic.

At first, this research represented the works of literature by theoretical interpretations which contribute to the consumer behavior field focusing the present global phenomena that have triggered severe turmoil in international society and individual's lives. Works of literature were reviewed to understand what the buying behavior is and to examine the state of the buying behavioral changes in crises. Based on the reviewed theoretical attempts and knowledge in this sector, the research hypotheses were formed and a research model was developed. The performed empirical research and subsequent analysis resulted that all of the hypotheses of the study were accepted. According to Bae and Chang (2020), The Health experts have emphasized getting prepared for the upcoming 2nd wave of COVID-19 and also declared that due to environmental changes several severe viruses like COVID-19 could be repeated regularly every 4-5 years. Expected 2nd wave of the pandemic in this winter after the short-term break from the global spread, the outcomes of this research will be certainly considered as a significant reference to future follow-up studies to notice consumers' both short-term and longterm behavioral modifications.

Second, the research model extended the "Theory of Planned Behavior" with the risk perception variable. Also, it established the intermediating role of attitudes and subjective norms between risk perception and behavioral intention. The outcomes of this research will deliver important insights into consumer behaviors during any outbreaks of contagious diseases like COVID-19 in the future.

This research offers practical inferences for the business and consumer market in Bangladesh as well as the global business and consumer market. It is possible to provide valuable insights such as panic purchasing, hoarding tendencies and virtual platforms adaptation into the changing behavior of the consumers, by analyzing consumer purchasing behavior during the COVID-19 pandemic. And also these insights can be of particular importance for the marketing departments of companies, retailers, producers. Business practitioners may need to consider online selling and home delivery system as the new paradigms that accommodate consumer's needs to minimize their perceived risks. Ultimately, these outcomes can be used to invent strategies on how to do business as usual during and after the pandemic.

The COVID-19 crisis is a crisis of a certain type, and it is not comparable to a financial crisis or a health crisis, it is unprecedented. Hence, this research work investigated the effects of COVID-19 on changed buying behavior. This study contributes to the business studies by explaining the purchasing behavior and what factors have impacts on it, and the results draw a conclusion about during and post-pandemic marketing strategies and policies for the business policymakers. The findings in this study can be used as a stepping stone for further research on consumer behavior because of its exploratory nature.

The outcomes indicate that there are changes in the buying behaviors of the consumers due to the pandemic. Because of the health and safety concern, imposed restrictions, financial conditions, surrounding environmentpeople, and other realities caused a remarkable change in consumer buying behavior.

\section{Limitations and Scope}

Despite the contributions, the study is not without limitation; Behavioral intention could change after the end of the COVID-19 pandemic. For examining the relationship between behavioral intentions in the previous time and real behavior in a later time, the research work may require further data collection for the longitudinal investigation of the matter over multiple periods. Also, the results of this research were founded on the population of Bangladesh and the study model should be authenticated in other circumstances. As the study was only able to explain a small part of the changed buying behavior and was conducted at a specific limited time in the pandemic, thus a study later in the pandemic could have come up with different results and would aid in explaining more of the changed buying behavior. 
The researchers were only able to carry out an online survey because of imposed social distancing. If there are no such restrictions, other methods such as a random sample test outside supermarkets and in several locations could be performed and the sample size could be large. A larger sample size can also identify differences between age groups along with the demographic differences. Depending on if the consumers lived in different countries it was also found to have a large significant effect on the changed buying behavior and reasons behind this outcome could be further investigated to explain the variances in transformed buying behaviors during the pandemic in various countries.

Multiple indicators for future research have been suggested by the study. The fact that buying behavior has changed and established panic buying shows that further research should be continued about changed buying behavior in various circumstances. The factors were found only to explain a smaller part of the influence on the changed buying behavior and consequently, there is an opportunity to discover extensively more influencing dimensions that could illuminate the changed buying behavior.

This study can be used as a motivator to research the changing trends of consumer goods. Furthermore, it is also relevant that the factors determined in this work can be tested on product categories. Lastly, a similar study could be conducted for future studies in the different time of the pandemic, so that the obtained results from this study could be compared with the future outcomes.

\section{References}

Ajzen, I. (1991). The theory of planned behavior. Organizational Behavior and Human Decision Processes, (online) 50(2), pp.179-211. Available at: https://www.dphu.org/uploads/attachements/books/books 4931 0.pdf. (07 Aug. 2020)

Alam, M.S., Alam, M.Z., Nazir, K.N.H. and Bhuiyan, M.A.B., (2020). The emergence of novel coronavirus disease (COVID-19) in Bangladesh: Present status, challenges, and future management. Journal of Advanced Veterinary and Animal Research, 7(2), pp.198-208. Available at: http://doi.org/10.5455/javar.2020.g4102020; 7(2):198-208. (11 Sep. 2020)

AMA - American Marketing Association Dictionary (2016) (https://www.ama. org/resources/Pages/Dictionary.aspx?dLetter=C; (11 May 2020)

Andersen, A., Hansen, E., Johannesen, N. and Sheridan, A. (2020). Pandemic, Shutdown and Consumer Spending: Lessons from Scandinavian Policy Responses to COVID-19 *. (online) Available at: https://arxiv.org/pdf/2005.04630.pdf. (10 Aug. 2020)

Ang, S.H., Leong, S.M. and Kotler, P., (2000). The Asian apocalypse: crisis marketing for consumers and businesses. Long Range Planning, 33(1), pp.97-119.

Avdiu, B. and Nayyar, G. (n.d.). When Face-to-Face Interactions Become an Occupational Hazard Jobs in the Time of COVID-19. (online) Available at: https://openknowledge.worldbank.org/bitstream/handle/10986/33752/When-Face-to-Face-InteractionsBecome-an-Occupational-Hazard-Jobs-in-the-Time-of-COVID-19.pdf?sequence=1(02 Sept. 2020)

Bae, S.Y. and Chang, P.-J. (2020). The effect of coronavirus disease-19 (COVID-19) risk perception on behavioural intention towards 'untact' tourism in South Korea during the first wave of the pandemic (March 2020). Current Issues in Tourism, pp.1-19.

Baker, S.R., Farrokhnia, R.A., Meyer, S., Pagel, M. and Yannelis, C. (2020). How Does Household Spending Respond to an Epidemic? Consumption During the 2020 COVID-19 Pandemic. SSRN Electronic Journal. (online) Available at: https://bfi.uchicago.edu/wp-content/uploads/BFI_WP_202030.pdf. (02 Sept. 2020)

Bray, J.P.( 2008). Consumer behaviour theory: approaches and models. (online) Available at: http://eprints.bournemouth.ac.uk/10107/1/Consumer_Behaviour Theory - Approaches \& Models.pdf (22 Aug. 2020)

Bayley, G., \& Nancarrow, C. (1998). Impulse purchasing: a qualitative exploration of thephenomenon. Qualitative Market Research: An International Journal, 1(2), 99-114.

Campbell, C., 2020. South Korea's health minister on how his country is beating Coronavirus without a lockdown. Time, April 30, 2020. (online) Available at: https://time.com/5830594/south-korea-covid19coronavirus/ (02 Sept. 2020)

CDC. (2020). Coronavirus (COVID-19). (online) Available at: https://www.cdc.gov/coronavirus/2019ncov/index.html (10 March 2020).

Chen, H., Qian, W. and Wen, Q. (2020). The Impact of the COVID-19 Pandemic on Consumption: Learning from High Frequency Transaction Data. SSRN Electronic Journal. (online) Available at: https://ssrn.com/abstract $=356857$ (02 Aug. 2020)

Chang, H.-J., Eckman, M., \& Yan, R.-N.(2011). Application of the Stimulus-Organism Response model to the retail environment: the role hedonic motivation in impulse buying behaviour. The International Review of Retail, Distribution and Consumer Research, 21(3), 233-249.

Chen, S.-C. and Hung, C.-W. (2016). Elucidating the factors influencing the acceptance of green products: An 
extension of theory of planned behavior. Technological Forecasting and Social Change, 112, pp.155-163. (online) Available at: https://isidl.com/wp-content/uploads/2017/08/E4675-ISIDL.pdf (12 Aug. 2020)

Chrysochou, P. (2017). Consumer Behavior Research Methods. Consumer Perception of Product Risks and Benefits, (online) pp.409-428. Available at: https://link.springer.com/chapter/10.1007/978-3-319-50530522 (12 Sept. 2020).

Coffey, C., Doorley, K., O'Toole, C. and Roantree, B. (2020). The effect of the COVID-19 pandemic on consumption and indirect tax in Ireland. (online) Available at: https://www.esri.ie/system/files/publications/BP202103.pdf (02 Sept. 2020).

Cohen, M.J. (2020). Does the COVID-19 outbreak mark the onset of a sustainable consumption transition? Sustainability: Science, Practice and Policy, 16(1), pp.1-3.

Cook, C., Hollowood, E. and Newell, C., 2020. Corona shock: Week II. (online) Available at: https://members.tortoisemedia.com/2020/04/28/corona-shock-week2/content.html. (24 Sept. 2020).

Daneshvary, R., and Schwer, R.K., (2000), "The Association Endorsement and Consumer's Intention to Purchase," Journal of Consumer Marketing, 17(3), pp. 203-213.

Dannenberg, P., Fuchs, M., Riedler, T. and Wiedemann, C. (2020). Digital Transition by COVID - 19 Pandemic? The German Food Online Retail. Tijdschrift voor economische en sociale geografie, 111(3), pp.543-560.

Deng, Y., Wang, M. and Yousefpour, R. (2017). How do people's perceptions and climatic disaster experiences influence their daily behaviors regarding adaptation to climate change? - A case study among young generations. Science of The Total Environment, 581-582, pp.840-847.

Donthu, N. and Gustafsson, A. (2020). Effects of COVID-19 on business and research. Journal of Business Research, 117, pp.284-289.

Durante, K.M. and Laran, J. (2016). The Effect of Stress on Consumer Saving and Spending. Journal of Marketing Research, 53(5), pp.814-828.

Eidelman, S. and Crandall, C.S. (2009). A Psychological Advantage for the Status Quo. Social and Psychological Bases of Ideology and System Justification, pp.85-106.

Engel, J.F., Blackwell, R.D., and Miniard, P.W., (1986), Consumer Behaviour, CBS College Publishing, New York.

Feng, C. and Fay, S. (2020). Store Closings and Retailer Profitability: A Contingency Perspective. Journal of Retailing.

Gázquez-Abad, J. C., Martínez-López, F. J., \& Esteban-Millat, I. (2017). The role of consumers' attitude towards econmic climate in their reaction to 'PL-only' assortments: Evidence from United States and Spain. Journal of Retailing and Consumer Services, 34, 340-348.

Hair, J.F., Tomas, Ringle, C. and Sarstedt, M. (2014). A Primer on Partial Least Squares Structural Equation Modeling (PLS-SEM). (online) Available at: http://hdl.handle.net/1959.13/1063732 (02 Oct. 2020).

Hamdah, D.F.L., Rahmadya, R.R. and Nurlaela, L., 2020. The Effect of Attitude, Subjective Norm, and Perceived Behavior Control of Taxpayer Compliance of Private Person in Tax Office Garut, Indonesia. Review of Integrative Business and Economics Research, 9, pp.298-306.. (online) Available at: https://sibresearch.org/uploads/3/4/0/9/34097180/riber 9-s1 23 k19-086 298-306.pdf (19 Sept. 2020).

Haq, M. and Abbasi, S. (2016). Indirect Impact of Hedonic Consumption and Emotions on Impulse Purchase Behavior: A Double Mediation Model. Journal of Management Sciences, 3(2), pp.108-122.

Henseler, J., Hubona, G. and Ray, P.A., 2016. Using PLS path modeling in new technology research: updated guidelines. Industrial management $\&$ data systems.

Henseler, J., Ringle, C. M., \& Sarstedt, M. (2015). A new criterion for assessing discriminant validity in variance-based structural equation modeling. Journal of the academy of marketing science, 43(1), 115-135.

Hu, L. and Bentler, P.M. (1998). Fit indices in covariance structure modeling: Sensitivity to under parameterized model misspecification. Psychological Methods, 3(4), pp.424-453.

Huynh, G., Nguyen, T.N.H., Vo, K.N. and Pham, L.A., 2020. Knowledge and attitude toward COVID-19 among healthcare workers at District 2 Hospital, Ho Chi Minh City. Asian Pacific Journal of Tropical Medicine, 13(6), p.260 (online) Available at:https://www.apjtm.org/article.asp?issn=19957645;year=2020; volume=13; issue=6; spage=260; epage=265; aulast=Huynh (21 Aug. 2020).

Islam, M.D. and Siddika, A. ( 2020) COVID-19 and Bangladesh: A study of the public perception on the measures taken by the government. (online) Available at: https://edarxiv.org/h7sbe/ (Accessed 28 Aug. 2020).

Islam S, Khan MZR. A review of energy sector of Bangladesh. Enrgy Proced (2017), 110: 611-8; https://doi.org/10.1016/j.egypro.2017.03.193

Jribi, S., Ben Ismail, H., Doggui, D. and Debbabi, H. (2020). COVID-19 virus outbreak lockdown: What impacts on household food wastage? Environment, Development and Sustainability, 22(5), pp.3939-3955.

Kaswengi, J., \& Diallo, M. F. (2015). Consumer choice of store brands across store formats: A panel data 
analysis under crisis periods. Journal of Retailing and Consumer Service, 23, 70-76.

Kirk, C.P. and Rifkin, L.S. (2020). I'll Trade You Diamonds for Toilet Paper: Consumer Reacting, Coping and Adapting Behaviors in the COVID-19 Pandemic. Journal of Business Research.

LankaBangla Asset Management Company Limited, 2020. COVID-19 Impact on Bangladesh Economy. Accessed 23 September 2020. (online) Available at: http://lbamcl.com/wp-content/uploads/2020/06/Covid19-Impact-on-Bangladesh-Economy.pdf (18 Aug. 2020).

Larson, L.R.L. and Shin, H. (2018). Fear During Natural Disaster: Its Impact on Perceptions of Shopping Convenience and Shopping Behavior. Services Marketing Quarterly, 39(4), pp.293-309.

Lohmöller, J.B. (2013). Latent variable path modeling with partial least squares. Springer Science \& Business Media.

Long, N.N. and Khoi, B.H. (2020). An Empirical Study about the Intention to Hoard Food during COVID-19 Pandemic. EURASIA Journal of Mathematics, Science and Technology Education, 16(7), p.em1857.

Mansoor, D. and Jalal, A. (2010). The Global Business Crisis and Consumer Behavior: Kingdom of Bahrain as a Case Study. International Journal of Business and Management, (online) 6(1). Available at: https://pdfs.semanticscholar.org/55f8/5c69644c6b13ad414588672138ffdb45c3bf.pdf. (18 Aug. 2020).

Mitchell, V.-W., \& Harris, G. (2005). The importance of consumers' perceived risk in retail strategy. European Journal of Marketing, 39(7/8), 821-837.

Mueller, S., \& Szolnoki, G. (2010). The relative influence of packagning, labeling branding and sensory attributes on liking and purchase intent: Consumers differ in their responsiveness . Food Quality and Preferance, 21(7), 774-783.

Munbodh, E. (2020). More than 20,000 shops that have closed during lockdown will never reopen. (Online) mirror. Available at: https://www.mirror.co.uk/money/coronavirus-more-20000-shops-closed-21756815. (20 Sept. 2020)

Murray, D.R. and Schaller, M. (2011). Threat(s) and conformity deconstructed: Perceived threat of infectious disease and its implications for conformist attitudes and behavior. European Journal of Social Psychology, 42(2), pp.180-188.

Nielsen, C.P.G., FMCG \& RETAIL. 2020. Key consumer behavior thresholds identified as the coronavirus outbreak evolves. (Online) Available at: https://www.nielsen.com/bd/en/insights/article/2020/keyconsumer-behavior-thresholds-identified-as-the-coronavirus-outbreak-evolves/ (12 Sept. 2020)

Patel, V., Chisholm, D., Dua, T., Laxminarayan, R. and Medina-Mora, M.L. eds., (2016). Disease Control Priorities, Third Edition (Volume 4): Mental, Neurological, and Substance Use Disorders. (online) Available at: https://www.ncbi.nlm.nih.gov/books/NBK361945/ (30 Aug. 2019).

Rao, M.J. and Moorthy, S., 2020. Analysis on Consumers Online Buying Behavior of Essentials during COVID 19 in Central Suburbs of Mumbai. Purakala with ISSN 0971-2143 is an UGC CARE Journal, 31(37), pp.440-452.

Rhee, H., \& Bell, D. R. (2002). The inter-store mobility of supermarket shoppers. Journal of Retailing, 78, 225237.

Rogers, S. (20200. How virtual reality could help the travel \&tourism industry in the aftermath of the coronavirus outbreak. Forbes, March 18. (online) Available at: https://www.forbes.com/sites/solrogers/2020/03/18/virtual-reality-and-tourism-whatsalready-happening-isit-the-future/\#af6202c28a6a (30 Jul. 2020)

Sharma, B.R., (2020). DON'T MISS THE FOREST FOR THE TREES: MANAGING CUSTOMER SATISFACTION, TRUST AND LOYALTY IN RETAILING DURING COVID-19. (online) Available at: https://www.researchgate.net/profile/Bodh Sharma/publication/343107479 DON'T MISS THE FOREST FOR THE TREES MANAGING CUSTOMER SATISFACTION TRUST AND LOYALTY IN RE TAILING DURING_COVID19/links/5f1719fd299bf1720d56c560/DONT-MISS-THE-FOREST-FORTHE-TREES-MANAGING-CUSTOMER-SATISFACTION-TRUST-AND-LOYALTY-IN-RETAILINGDURING-COVID-19.pdf (03 Aug. 2020)

Sheth, J. (2020). Impact of Covid-19 on Consumer Behavior: Will the Old Habits Return or Die? Journal of Business Research, 117, pp.280-283.

Sneath, J. Z., Lacey, R., \& Kennett-Hensel, P. A. (2009). Coping with natural disaster:Losses, emotions, and impulsive and compulsive buying. Marketing Letters, 20(1), 45-60.

Stanciu, S., Radu, R.I., SAPIRA, V., BRATOVEANU, B.D. and FLOREA, A.M.(2020). Consumer Behavior in Crisis Situations. Research on the Effects of COVID-19 in Romania. Annals of the University Dunarea de Jos of Galati: Fascicle: I, Economics \& Applied Informatics, 26(1). (Online) Available at: https://www.researchgate.net/profile/Silvius_Stanciu/publication/341266228_Consumer_Behavior_in_Crisi s_Situations_Research_on_the_Effects_of_COVID19 in_Romania/links/5eb6754b4585152169c110dd/Consumer-Behavior-in-Crisis-Situations-Research-onthe-Effects-of-COVID-19-in-Romania.pdf (08 Aug. 2020) 
Van Bavel, J.J., Baicker, K., Boggio, P.S., Capraro, V., Cichocka, A., Cikara, M., Crockett, M.J., Crum, A.J., Douglas, K.M., Druckman, J.N. and Drury, J.(2020). Using social and behavioural science to support COVID-19 pandemic response. Nature Human Behaviour, pp.1-

Vancic, A. and Pärson, G.F.A.(2020). Changed Buying Behavior in the COVID-19 pandemic: the influence of Price Sensitivity and Perceived Quality.

World Health Organization (2020). Coronavirus disease (COVID-19) pandemic. (Online) Available at: https://www.who.int/emergencies/diseases/novel-coronavirus-2019?gclid=EAIaIQobChMI1_TcwO7AIVgTgrCh1QLwyVEAAYASAAEgLqE_D_BwE (19 Oct. 2020)

$\mathrm{Yu}, \overline{\mathrm{C}}$. and Bastin, M. (2010). Hedonic shopping value and impulse buying behavior in transitional economies: A symbiosis in the Mainland China marketplace. Journal of Brand Management, 18(2), pp.105-114.

Zwanka, R.J. and Buff, C. (2020). COVID-19 Generation: A Conceptual Framework of the Consumer Behavioral Shifts to Be Caused by the COVID-19 Pandemic. Journal of International Consumer Marketing, pp. $1-10$ 